\title{
Are State-Ranking Indicators Correlated with State Economic Performance?
}

Yu Hsing, Southeastern Louisiana University

Michael C. Budden, Southeastern Louisiana University

\begin{abstract}
A variety of rankings appear regularly in the popular press. Such rankings purport to indicate livability, economic well-being, crime propensity, obesity, and business climate, to name a few. An investigation was conducted to assess whether state-ranking indicators developed by Forbes would be correlated with overall economic performance. We find that labor and quality of life have relatively high correlation with per capita gross state product; that business costs, the economic climate, and quality of life are well correlated with the unemployment rate; and the negative impact of high business costs on the growth rate of civilian employment is relatively high. The correlation coefficient between business costs and per capita gross state product has an unexpected sign. Growth prospects exhibit little correlation with state overall economic performance. The relatively low correlation coefficient between overall ranking and per capita gross state product or the growth rate of civilian employment suggests that it is not a good predictor for state workforce productivity or employment growth.
\end{abstract}

Keywords: state rankings, correlation, economic performance, predictions

\section{INTRODUCTION}

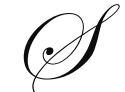

tate rankings for business are critical. State governments take pride when rankings are relatively high. Ostensibly, businesses review state rankings in making decisions for factory locations and investment projects. Households may use state rankings in making decisions for migration or search of jobs. Foreign firms rely on state rankings in selecting factory or commercial sites. Once published, rankings may harm a state and result in a potential loss of businesses, employment, income, and population. Or, rankings may help states grow existing business, attract new business, and create opportunities that may not otherwise exist.

Over the years, news media or firms have tried to rank individual states based on various types of indicators. For example, Forbes (Badenhausen 2008) has published "The Best States for Business" for several years based on six criteria including business costs, labor, regulatory environment, economic climate, growth prospects, and quality of life. An overall ranking is also provided. In its 2008 article, Virginia, Utah, Washington, North Carolina, and Georgia were ranked as the top five states for business. CNBC (2009) released its state rankings for business based on ten criteria including cost of business, workforce, quality of life, economy, business friendliness, cost of living, education, transportation, technology \& innovation, and access to capital. Virginia, Texas, Colorado, Iowa, and Utah were the top five states for business in that CNBC study. Chief Executive (2009) reported U.S. best and worst states for 2009 based on nine criteria including cost of business, technology \& innovation, transportation, business friendliness, workforce, economy, education, quality of life, and access to capital. Texas, North Carolina, Florida, Georgia, and Tennessee were ranked as the top five states in Chief Executive's report. An analysis of these state-ranking reports indicates that rankings by these three agencies exhibit similarities and discrepancies. Colorado, North Carolina, Georgia, Texas and Virginia were consistently ranked among the top 10 states by all three reporting agencies. On the other hand, Florida was ranked $3^{\text {rd }}$ by Chief Executive, $8^{\text {th }}$ by Forbes, and $28^{\text {th }}$ by $C N B C$. Iowa was ranked $4^{\text {th }}$ by $C N B C$, the $19^{\text {th }}$ by Chief Executive, and $22^{\text {nd }}$ by Forbes. Massachusetts was ranked $8^{\text {th }}$ by $C N B C$, the $36^{\text {th }}$ by Forbes, and $47^{\text {th }}$ by Chief Executive.

The current study attempts to examine whether these individual state-ranking indicators are correlated with state overall economic performance as measured by per capita gross state product, the unemployment rate, or the growth rate of civilian employment. A relatively low correlation coefficient suggests that the state-ranking indicator may not be a good measure whereas a relatively high correlation coefficient shows that the state-ranking indicator may be a good indicator. Empirical results in this study will provide state policy makers with insights into state- 
ranking indicators in reviewing programs and improving rankings. Findings may also clarify and contribute to business decisions based on rankings.

There are several recent studies of employment growth, worker productivity, migration, state per capita personal income, return to education, and economic growth based on state data and rankings. Partridge and Rickman (1996) indicate that industry composition and taxes affect state employment growth whereas there is a lack of evidence that knowledge spillovers significantly influence state employment growth. Domazlicky and Weber (1998) present major findings that worker productivity in individual states will increase by attracting manufacturing industries and private capital, enhancing quality of labor force through education, and decentralizing economic activities in large metropolitan areas.

Based on state samples during 2000-2004, Cebula and Alexander (2006) found that the net in-migration rate among states is positively correlated with median family income, state and local government spending per pupil on primary and secondary education, the lagged employment growth, warmer climate rate and negatively associated with the cost of living, state and local individual income tax burden, presence of hazardous waste sites, and toxic chemical releases. Bauer, Schweitzer, and Shane (2006) indicate that state knowledge stocks as measured by the number of patents and educational attainment rates are the major variables for changes in state per capita personal income.

Using a sample of individual states during 1840-2000, Turner, Tamura, Mulholland, and Baier (2007) estimate that the return to a year of schooling is $11 \%-15 \%$. The range is robust to different time periods, methodologies, and assumptions. Bania, Gray, and Stone (2007) reveal that the Barro-Style model applies to the U.S. states as economic growth will first rise with more taxes spent on productive public goods such as education, highways and public safety and then becomes negative due to a depressed net return on private capital. These and other previous works have made significant contributions to the understanding of the subjects under study. To the authors' best knowledge, few of the previous studies have examined whether these state-ranking studies would be good predictors for state worker productivity, unemployment rate or employment growth.

\section{THE MODEL} performance:

In this study, consider the following three dependent variables to represent state overall economic

- $\quad$ PCGSP $=$ per capita gross state product in 2008

- $\quad \mathrm{UNEMP}=$ the unemployment rate in 2008 , and

- $\quad$ GREMP $=$ growth rate of civilian employment during 2007-2008.

Forbes reports an overall ranking and six individual state-ranking indicators as follows:

- $\quad$ ALLRANK = overall ranking,

- $\quad$ BUSCOST $=$ business costs,

- $\quad$ LABOR $=$ labor,

- $\quad$ REGENV = regulatory environment,

- $\quad \mathrm{ECONCL}=$ economic climate,

- $\quad$ GROWTHP $=$ growth prospects, and

- $\quad$ QUALITY = quality of life.

Business costs are constructed from costs of taxes, labor, and energy. Labor is represented by projected population growth, educational attainment, and net migration. More population growth indicates potential increase in business opportunities. As more people migrate to a state, it suggests that more job opportunities may be available. Regulatory environment measures the regulatory and tort climate, incentives, transportation and bond ratings. Economic climate measures income, job and gross state product growth, unemployment, and presence of large firms. Growth prospects reflect predicted job, income, and gross state product growth, business openings/closings, and venture capital investments. Quality of life is constructed from several variables including poverty rates, cost of living, schools, crime, and health. Note that values of these state-ranking variables range from 1 (the best) to 50 (the worst). The sample consists of 50 states in the U.S. Washington, D.C. is not included in Forbes' study. 
We expect that a higher ranking of these indicators would increase per capita gross state product, reduce the unemployment rate, and increase the growth rate of civilian employment. In other words, these state-ranking indicators should have a negative correlation with per capita gross state product, a positive correlation with the unemployment rate, and a negative correlation with the growth rate of civilian employment. The expected signs of the correlation between each of the state overall economic performance and state-ranking indicators are presented below:

$\begin{array}{lccc} & \text { PCGSP } & \text { UNEMP } & \text { GREMP } \\ \text { ALLRANK } & - & + & - \\ \text { BUSCOST } & - & + & - \\ \text { LABOR } & - & + & - \\ \text { REGENV } & - & + & - \\ \text { ECONCL } & - & + & - \\ \text { GROWTHP } & - & + & - \\ \text { QUALITY } & - & + & -\end{array}$

\section{EMPIRICAL RESULTS}

The correlation coefficients between per capita gross state product in 2008, the unemployment rate in 2008, or the growth rate of civilian employment during 2007-2008 and all the state-ranking indicators are presented in Table 1.

Table 1: Correlation Analysis

\begin{tabular}{lrrr} 
& PCGSP & UREMP & GREMP \\
\cline { 2 - 4 } ALLRANK & -0.137434 & 0.350521 & -0.052369 \\
BUSCOST & 0.327352 & 0.330645 & -0.316258 \\
LABOR & -0.438930 & 0.164818 & 0.084842 \\
REGENV & 0.133442 & -0.126693 & 0.039723 \\
ECONCL & -0.145917 & 0.299606 & 0.044237 \\
GROWTHP & -0.063051 & -0.003364 & 0.094509 \\
QUALITY & -0.472460 & 0.199794 & -0.006241
\end{tabular}

A higher correlation coefficient suggests that the state-ranking indicator may have a larger impact on the dependent variable, holding other variables constant. For example, the correlation coefficient between per capita gross state product and labor or quality of life is relatively high suggesting a better labor quality or a better quality of life would have a positive impact on per capita gross state product. Note that the positive sign of the correlation coefficient for business costs is likely to be wrong because a higher ranking should increase per capita gross state product.

Furthermore, the correlation coefficients between the unemployment rate and overall ranking, business costs, economic climate, and quality of life are relatively high, suggesting that a higher overall ranking, a lower business cost, a better economic climate, or a better quality of life would reduce the unemployment rate. Note that the sign of the correlation coefficient for the economic environment or growth prospects is opposite to the expected positive sign.

In analyzing the relationship between the growth rate of civilian employment and state-ranking indicators, we find that only the variable of business costs has a relatively high correlation coefficient, suggesting that a lower business cost would increase employment growth.

\section{SUMMARY AND CONCLUSIONS}

This paper examined the correlation between state overall economic performance and the 2008 state rankings for business published by Forbes magazine. The sample consists of the 50 states. The correlation analysis is employed in empirical work. Per capita gross state product has a relatively high correlation with labor or quality of life, that the unemployment rate has a relatively high correlation with the overall ranking, business costs, the economic climate or quality of life, and that the growth rate of civilian employment has a relatively high correlation with business costs. The positive correlation coefficient between per capita gross state product and business costs is contrary to what was expected because it would be puzzling if higher business costs would lead to a higher per 
capita gross state product.

There are several policy implications. First, the potential impact of state rankings for business is large. Hence, state governments need to review these reports to find ways to improve the statistics. Second, in applying these rankings, businesses and households may need to exert caution as some of these indicators may not have a significant correlation with worker productivity, unemployment or employment. Third, business costs and quality of life have relatively high correlations with two of the three state economic performance indicators. Therefore, an individual state may pay more attention to these two indicators and find ways to improve its rankings.

It seems that some of the state-ranking indicators may need to be reconstructed as they are not much correlated with state overall economic performance. For example, in this study, the variable of growth prospects is not much correlated with per capita gross state product, the unemployment rate, or the growth rate of civilian employment. Although the correlation analysis provides valuable information between one of the dependent variables and state-ranking indicators, other statistical analyses may be needed in order to examine the impact of one of the state-ranking indicators while holding other variables constant. Other studies by CNBC (2009) and Chief Executive (2009) may be examined as well in order to compare which state-ranking indicator(s) would be more correlated with state overall economic performance. If a state-ranking indicator has a relatively low correlation coefficient with one or some of the state economic performance variables, this indicator may need to be reexamined and reconstructed. In constructing a state-ranking indicator, different weights derived from econometric analysis may be assigned to each of the components.

\section{AUTHOR INFORMATION}

Dr. Yu Hsing is an internationally ranked economist with almost two decades of university administrative experience. His publications primarily use advanced statistical and econometric tools to investigate a variety of macroeconomic phenomena. Dr. Hsing is Professor of Economics at Southeastern Louisiana University.

Dr. Michael C. Budden is the Mayfield Professor of Marketing at Southeastern Louisiana University. His research interests include ethics, retail management and international marketing.

\section{REFERENCES}

1. Badenhausen, Kurt (2008) "Special Report: The Best States for Business," July 31, Forbes, http://www.forbes.com/2008/07/30/virginia-georgia-utah-biz-cz_kb_0731beststates.html.

2. Bania, Neil; Gray, Jo Anna; and Stone, Joe A. (2007) "Growth, Taxes, and Government Expenditures: Growth Hills for U.S. States," National Tax Journal, 60(2), June, 193-204.

3. Bauer, Paul W.; Schweitzer, Mark E.; and Shane, Scott (2006) "State Growth Empirics: The Long-Run Determinants of State Income Growth," Federal Reserve Bank of Cleveland, Working Paper: 0606.

4. Cebula, Richard J.; and Alexander, Gigi M. (2006) "Determinants of Net Interstate Migration, 2000-2004," Journal of Regional Analysis and Policy, 36(2), 116-123.

5. $\quad$ Chief Executive (2009) "US Best and Worst States For Business - 2009,"

http://www.chiefexecutive.net/media/usbestandworststates/2009/.

6. $\quad$ CNBC (2009) "America's Top States for Business 2009 - Overall Rankings," http://www.cnbc.com/id/31765926.

7. Domazlicky, Bruce R.; and Weber, William L. (1998) "Determinants of Total Factor Productivity, Technological Change, and Efficiency Differentials among States, 1977-86," Review of Regional Studies, 28(2), Fall, 19-33.

8. Partridge, Mark D.; and Rickman, Dan S. (1996) "The Role of Industry Structure, Costs, and Economic Spillovers in Determining State Employment Growth Rates," Review of Regional Studies, 26(3), Winter, 235-264.

9. Turner, Chad; Tamura, Robert; Mulholland, Sean E.; and Baier, Scott (2007) "Education and Income of the States of the United States: 1840-2000," Journal of Economic Growth, 12(2), June, 101-158.

10. U.S. Bureau of Economic Analysis (2009) "Gross Domestic Product by State," http://www.bea.gov/regional/gsp/.

11. U.S. Census Bureau (2009) "National and State Population Estimates," http://www.census.gov/popest/states/NST-ann-est.html.

12. U.S. Department of Labor (2009) "State and Metro Area Employment, Hours, \& Earnings," http://www.bls.gov/sae/.

13. U.S. Department of Labor (2009) "Local Area Unemployment Statistics," http://www.bls.gov/lau/. 